\title{
EFFECT OF SEED TUBER SIZE AND PLANTING SPACE ON GROWTH, YIELD AND TUBER SIZE DISTRIBUTION OF POTATO (SOLANUM TUBEROSUM) IN IRRIGATED RED-YELLOW LATOSOLS OF THE DRY ZONE
}

\author{
S. RAJADURAI \\ Department of Agronomy, Faculty of Agriculture, University of Jaffna, Kilinochchi.
}

(Received : 16 August 1993, accepted : 06 June 1994)

\begin{abstract}
Effect of seed tuber size and planting space on tuber yield and tuber size of potato (S.tuberosum) was studied in red-yellow latosols of dry zone under irrigation. It was found that the number of stems and tubers produced per plant significantly increased with increasing seed tuber size and planting space. The numbers of stems and tubers per plant were significantly associated. Narrow spacing increased the yield per hectare but decreased the yield per plant: Production of large size tubers were not influenced by the size of seed tubers. planted. However increasing planting space increased the production of largesize tubers. Because of the high seed cost, income may be optimized if the seed tubers are sorted according to size and planted in $60 \times 20 \mathrm{~cm}, 60 \times 30 \mathrm{~cm}$, and $60 \times 50 \mathrm{~cm}$ spacings respectively.
\end{abstract}

Key words: Seed tuber size, planting space, potato, stem number, Solanum tuberosum, tuber yield.

\section{INTRODUCTION}

The potato (S.tuberosum) is one of humanity's most valuable food crops. It ranks fourth in the world in production after rice, wheat and maize. In dollar value it is fifth in developing countries after rice, wheat, maize and cassava. ${ }^{1}$ In the yield of edible energy and proteins per hectare per day, potato is near the top of the list of major world food crops. ${ }^{1}$ In recent years the growth rate of potato production in developing countries has exceeded that of most other food crops. ${ }^{1}$

The potato gives a very high income per day compared to other crops in Sri Lanka. On average Rs.200,000 can be obtained as net income from one hectare in three months time (personal communications and farm records). In Sri Lanka, and in particular in the dry zone, the cost of seed tubers accounts for $50 \%$ of the total variable cost of production (personal communication and farm records). Because of variable returns, only few affluent farmers specialize in potato cultivation. Potato was first introduced in the dry zone in early 1960's in the Jaffna district. It is now cultivated in many parts of the dry zone areas during Maha season from November to March. Small and medium size seed tubers are prefered by farmers engaged in small scale cultivation to reduce seed costs.

However, the optimum spacing for different size of seed tubers and their effects on growth, yield and tuber size distribution have not been studied under dry zone irrigated conditions. It is reported that planting large size seed tubers increased the tuber number and yield per plant over small size tubers. ${ }^{2,3}$ The 
optimum spacings for different sizes of seed tubers that maximise tuber yield under irrigated dry zone conditions are reported here.

\section{METHODS AND MATERIALS}

The field experiments were conducted at the Faculty of Agriculture, Kilinochchi in red-yellow latosols during Maha 1992/93 under irrigation. The experiment was laid out in a split-plot design with seed tuber size in main plot and planting space in subplot. Three different size seed tubers with diameters $15-30 \mathrm{~mm}$ (small), $30-45 \mathrm{~mm}$ (medium), $45-55 \mathrm{~mm}$ (large) with three spacings $60 \times 20 \mathrm{~cm}, 60 \times 30 \mathrm{~cm}$ and $60 \times 50 \mathrm{~cm}$ were tested. Desiree cultivars of $31 / 2 \mathrm{months}$ were used. Seed tubers were sprouted to $5 \mathrm{~mm}$ by reducing light before planting to obtain uniform and quick germination.

Fertilizer was applied as recommended by the Department of Agriculture. viz. $52.5 \mathrm{~kg} \mathrm{~N}, 110 \mathrm{~kg} \mathrm{P}_{2} \mathrm{O}_{5}$ and $45 \mathrm{~kg} \mathrm{~K}_{2} \mathrm{O}$ per hectare applied basally and a further $52.5 \mathrm{~kg} \mathrm{~N}$ and $45 \mathrm{~kg} \mathrm{~K}_{2} \mathrm{O}$ after 30 days. Growth parameters and yield components recorded were the number of stems, leaf area index(LAI), number of tubers, tuber size distribution and tuber weight. Analysis of variance for split plot design was performed and least significant difference computed for different mean comparisons.

\section{RESULTS}

\section{Number of stems and leaf area index (LAI)}

Tubers germinated within ten days. Number of stems per tuber were recorded at tuber initiation stage which occured 15 days after germination(Table 1 ). It was found that the number of stems produced per tuber increased with increasing tuber size and spacing. Large size seed tubers produced more stems than small ones. Large and medium size seed tubers significantly increased stem numbers over small size seed tubers. Number of stems produced by seed tubers planted at $60 \times 30 \mathrm{~cm}$ spacing was significantly higher at a spacing $60 \times 20 \mathrm{~cm}$. However differences between $60 \times 30 \mathrm{~cm}$ and $60 \times 50 \mathrm{~cm}$ spacings were not significant.

This is in accordance with earlier findings. ${ }^{4}$ Positive linear regression was found between the number of stems and number of tubers produced per plant $\left(r=0.977^{+*}\right)$. Leaf area index at tuber initiation stage was not influenced by seed tuber size. It was found that LAI decreased with increasing planting space at tuber initiation time.

\section{Tuber number and yield}

Number of tubers per plant increased with increasing seed tuber size and planting space. Large size seed tubers produced significantly more number of .tubers over small (Table 2). Wiersema ${ }^{5}$ found a similar pattern in his field study. Number of tubers produced per plot significantly reduced with increasing 


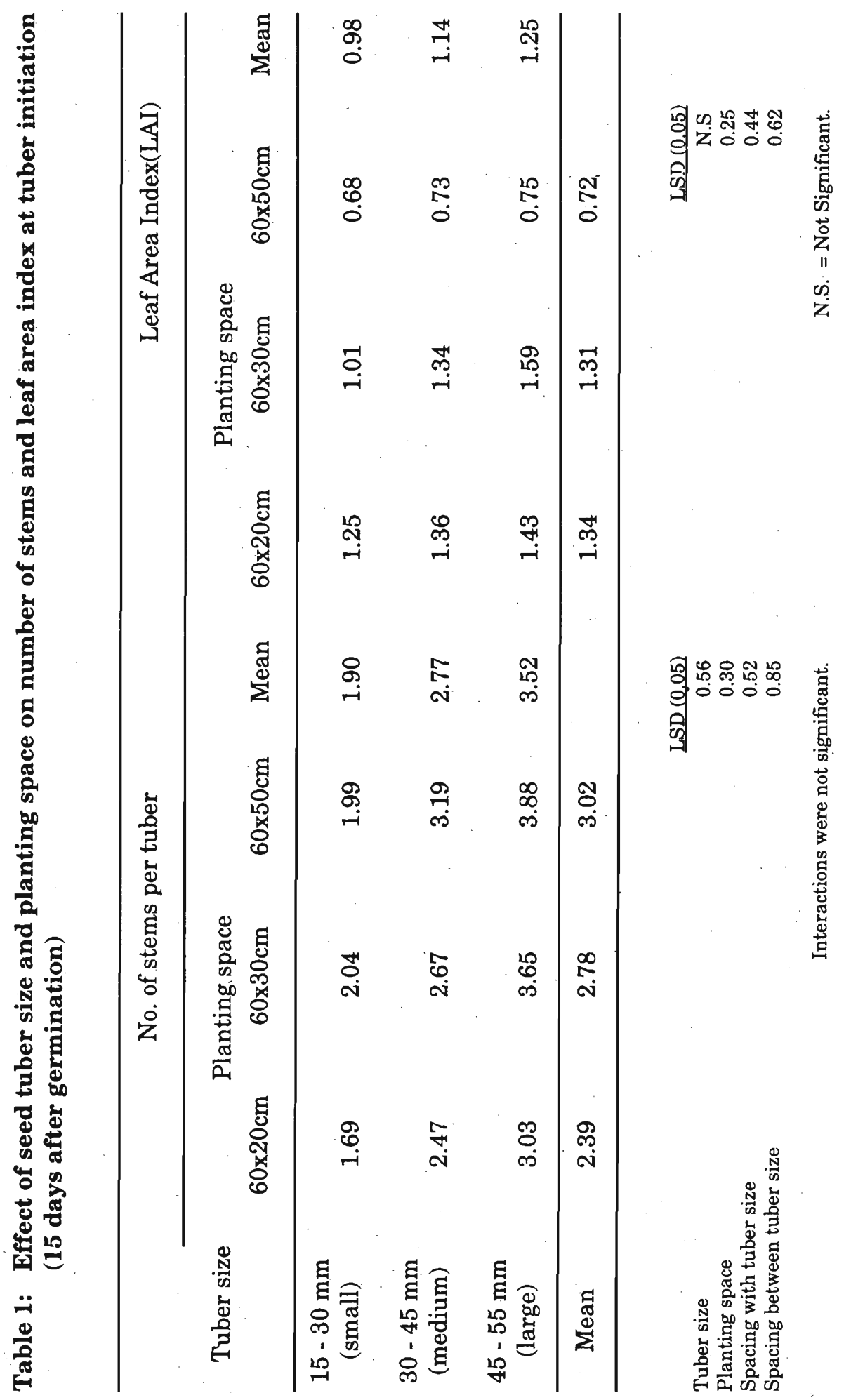




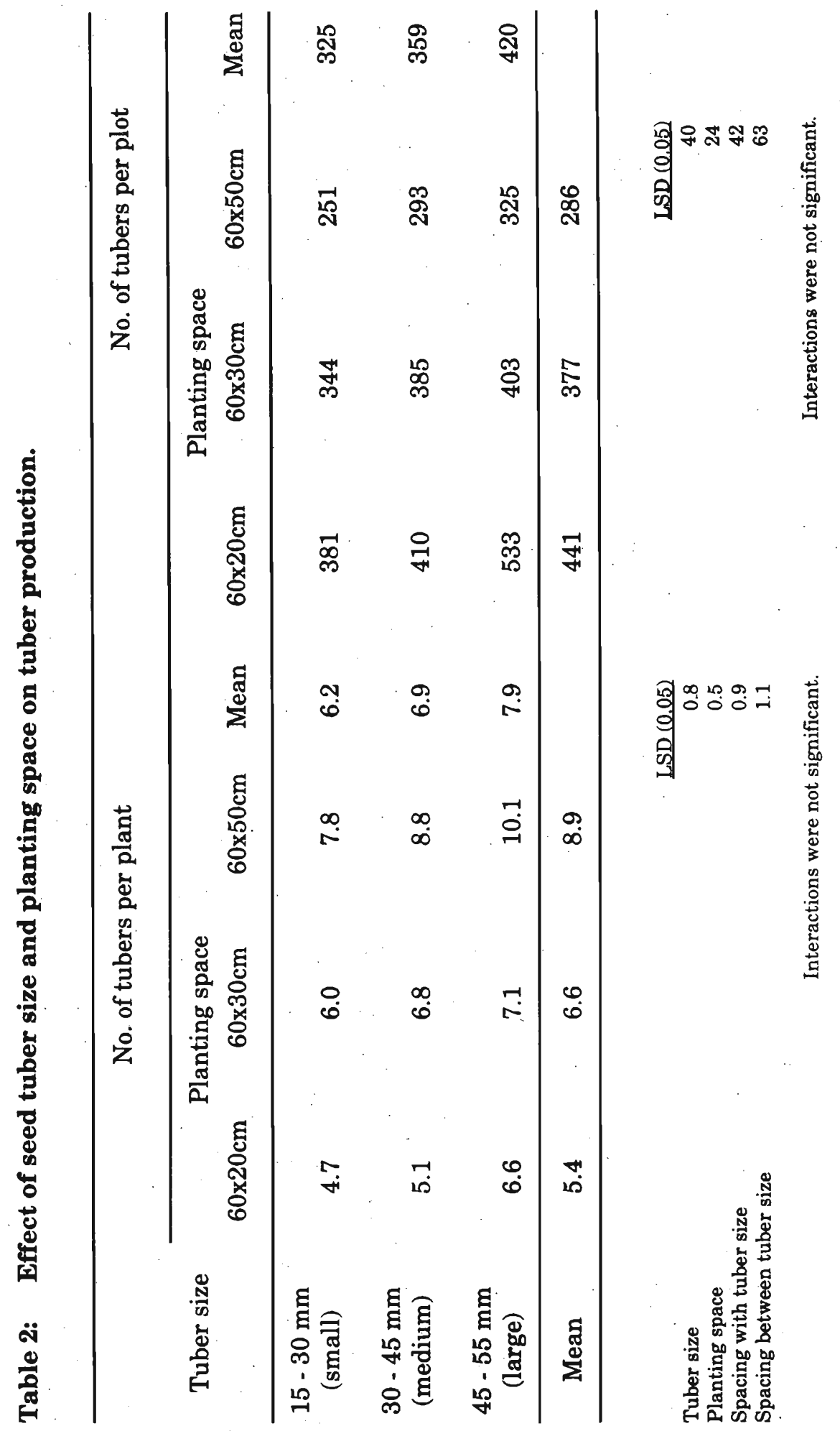


planting space. Tuber number per plot increased with increasing seed tuber size. However the difference in tuber numbers between small and medium sized seed tubers were not significant.

Narrow spacing increased the hectare yield and decreased the yield per plant. The highest yield was obtained with large size seed tubers $(45-55 \mathrm{~cm})$ planted in narrow spacing $(60 \times 20 \mathrm{~cm})$ (Table 3$)$. However the combination of large size seed tubers and narrow spacing produced many small size tubers of low market value. In this combination, the plant height increased and lodged due to high plant population.

Table 3: Effect of seed tuber size and planting space on tuber yield (MT/Ha)

\begin{tabular}{|c|c|c|c|c|}
\hline Tuber size & $60 \times 20 \mathrm{~cm}$ & $\begin{array}{l}\text { anting space } \\
60 \times 30 \mathrm{~cm}\end{array}$ & $60 \times 50 \mathrm{~cm}$ & Mean \\
\hline $\begin{array}{c}15-30 \mathrm{~mm} \\
(\mathrm{small})\end{array}$ & 24.43 & 20.89 & 17.20 & 20.84 \\
\hline $\begin{array}{c}30-45 \mathrm{~mm} \\
\text { (medium) }\end{array}$ & 24.22 & 24.89 & 20.88 & 23.31 \\
\hline $\begin{array}{c}45-55 \mathrm{~mm} \\
\text { (large) }\end{array}$ & 28.45 & 24.34 & 21.23 & 24.67 \\
\hline Mean & 25.70 & 23.37 & 19.75 & \\
\hline & $\begin{array}{l}\text { Tubber size } \\
\text { Spacing } \\
\text { Spacing with tube } \\
\text { Spacing between } t\end{array}$ & & $\begin{array}{r}\mathrm{LSD}(0.05) \\
2.16 \\
1.89 \\
3.29 \\
3.67\end{array}$ & \\
\hline
\end{tabular}

\section{Tuber size distribution}

Tuber size distribution was not significantly influenced by different size of seed tubers (Table 4). The production of large size tubers were found to be more than $50 \%$ in all treatments. However increasing planting space increased the population of large size tubers.

\section{Seed tuber cost and income}

The only variable cost considered in this experiment is the cost of seed tubers. The costs of other inputs, losses due to pests, disease and harvesting costs have not been taken into consideration in the following calculation. Cost of seed tubers, total income and the income after deducting the seed tuber cost are 


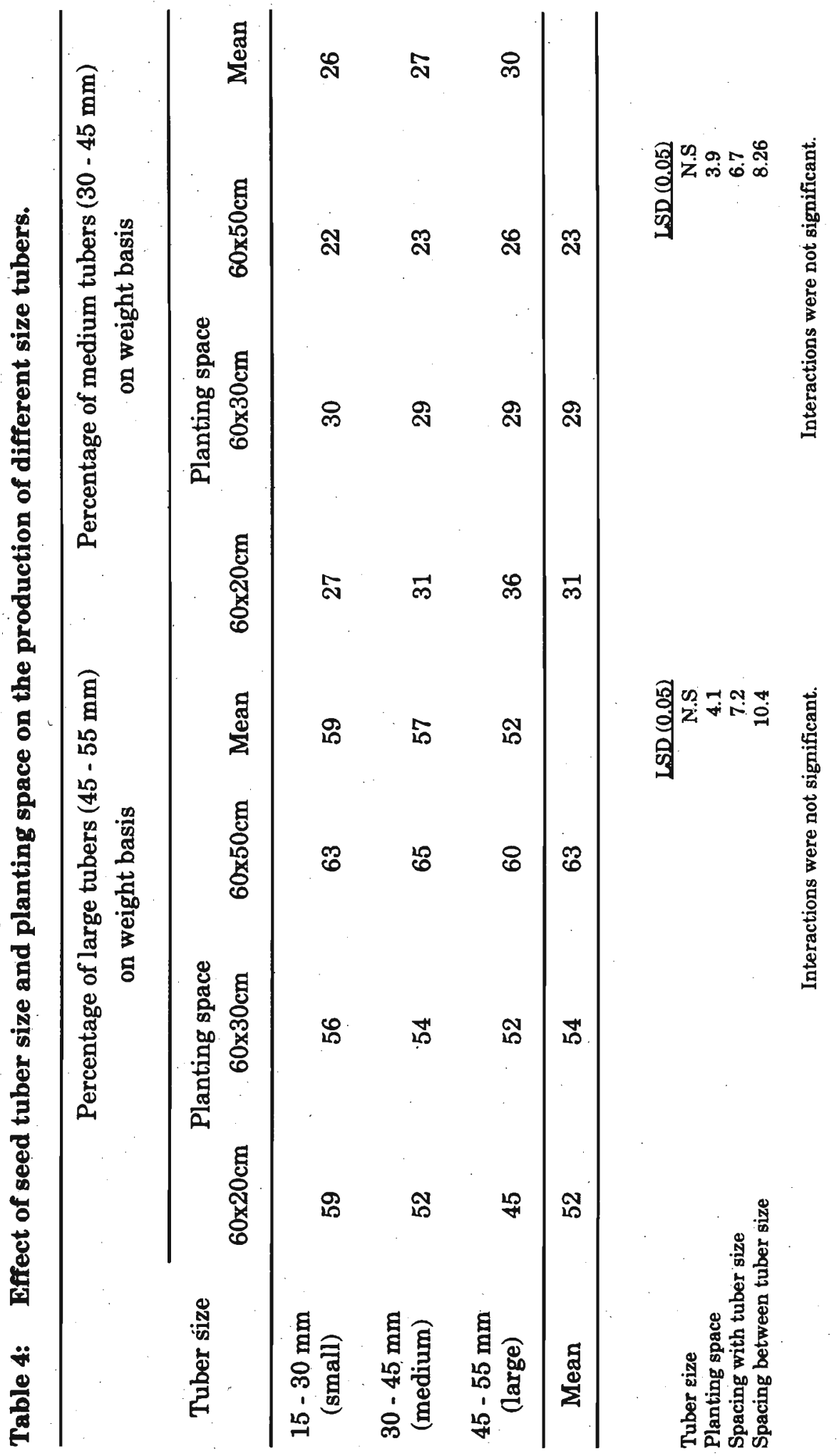




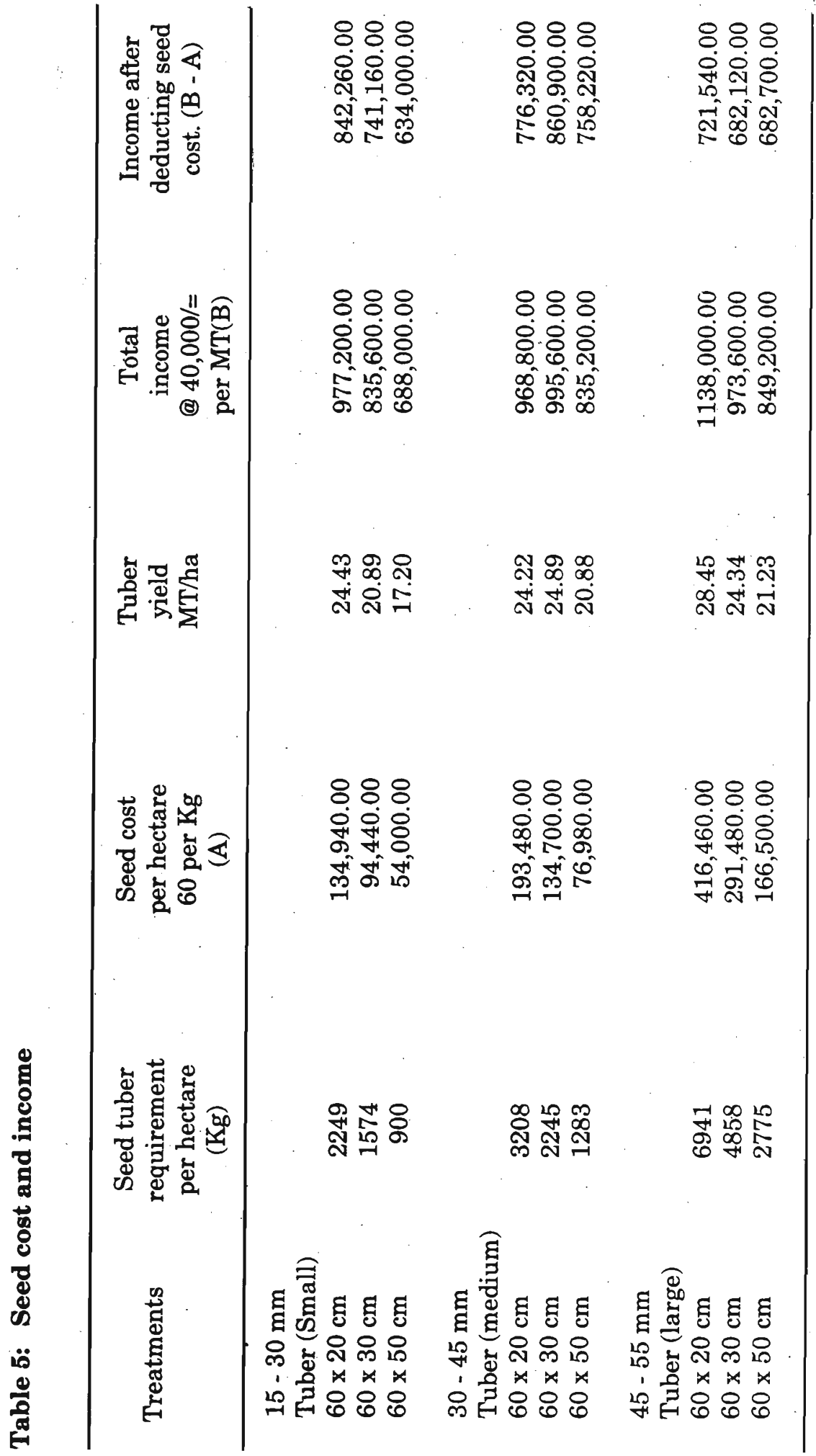


presented in detail (Table 5). The income level of different tuber size indicates that the highest income with small, medium and large size seed tubers can be obtained at $60 \times 20 \mathrm{~cm}, 60 \times 30 \mathrm{~cm}$ and $60 \times 50 \mathrm{~cm}$ spacing respectively. However, large size seed tubers planting in narrow spacing $(60 \times 20 \mathrm{~cm})$ is not recommended because of the small tubers produced and lodging.

\section{DISCUSSION}

The marked reduction in LAI at $60 \times 50 \mathrm{~cm}$ spacing may be attributed to the large land area the plants occupied. Attaining optimum LAI at early stage of growth is necessary to intercept maximum light energy ${ }^{6,7}$ Khurana and Mc Lared ${ }^{6}$ found that light interception by a potato crop canopy increased linearly with increasing LAI up to 2.25. Beyond 2.25 light interception increased at decreasing rate until a LAI of 4.0 was attained, at which point about $95 \%$ of the incoming radiation was intercepted: Increased number of stems per plant also increases the number of stolons which finally develop as tubers. This indicates a positive linear relationship between the number of stems and number of tubers developed per plant. Increased tuber yield per hectare at closer space may be attributed to high plant population. Sidhu et.al. ${ }^{2}$ reported that high yield could be obtained at closer spacing.

Number of tubers produced per plant was less with small seed tubers but it produced more large tubers. This may be because all the photo assimilates are translocated to few tubers and they increase in size. When the photo assimilates are distributed among a larger number of tubers, the percentage of large tubers is reduced. Analysis of variance performed for tuber yield and other important agronomic characters failed to find interaction between tuber size and planting space.

The results suggest varying planting space for different sizes of seed tubers to obtain optimum economic yield. ${ }^{2,8}$ Based on yield, tuber size distribution and other agronomic characters, the cost of seed tubers, market preference and price of yield of different size tubers, the spacing of $60 \times 20 \mathrm{~cm}, 60 \times 30 \mathrm{~cm}$, and $60 \times 50$ $\mathrm{cm}$ is recommended for small, medium and large size seed tubers respectively. Farmers, instead of planting different sizes of seed tubers using the same planting distance, can separate the seed tubers according to small, medium and large sizes and use the recommended spacing for each seed tuber size to maximize their income.

\section{References}

1. Douglas Horton \& Richard L.Sawyer (1985). The potato as a world food crop, with special reference to developing areas. In Potato physiology (Ed. H.L.I. Paul) pp. 1-7. Academic Press Inc. New York.

2. Sidhu A.S., Pandita M.L.,Arora S.K. (1982). Effect of seed size and spacing on growth and yield of potato. Journal of Indian Potato Association 9(2\&4): $69-73$. 
3. Szlavic I. \& Cassar K. (1989). Effect of different physiological age and seed tuber size on yield parameters and yield of potatoes cv granoda. Journal of Agronomy and Crop Science 163 (3): 245 -159.

4. Al Hassan A.I.M., Al Assaf M.A. \& Darweesh A.J. (1988). Effect of planting distance and seed tuber sizes on growth, tuberization and yield of potato. Mesopotamia Journal of Agriculture 20(2): 89 - 103.

5. Wiersema. S.G. (1989). Comparative performance of three small seed tuber size and standard size seed tubers planted at similar stem densities. Potato Research 32 (1): 81 -89.

6. Khurans S.L. \& Mc Laren J.S. (1982). The influence of leaf area, light interception and season on potato growth and yield. Potato Research 25: 329 -342 .

7. Zelitch I. (1975). Improving the efficiency of photo synthesis in potato Science 188: 626 -633.

8. Basu T.K. (1989). Growth, development and yield of potato tubers in response to population, inter and intra row spacings and seed size. Environment and Ecology 42: 633-638. 